\title{
Beaker people in Britain: migration, mobility and diet
}

\author{
Mike Parker Pearson ${ }^{1}$, Andrew Chamberlain ${ }^{2}$, Mandy Jay ${ }^{3,4}$, \\ Mike Richards ${ }^{5}$, Alison Sheridan ${ }^{6}$, Neil Curtis ${ }^{7}$, Jane Evans ${ }^{8}$, \\ Alex Gibson ${ }^{9}$, Margaret Hutchison ${ }^{7}$, Patrick Mahoney ${ }^{10}$, \\ Peter Marshall ${ }^{11}$, Janet Montgomery ${ }^{4}$, Stuart Needham ${ }^{12}$, \\ Sandra O'Mahoney ${ }^{13}$, Maura Pellegrini ${ }^{14} \&$ Neil Wilkin ${ }^{15}$
}

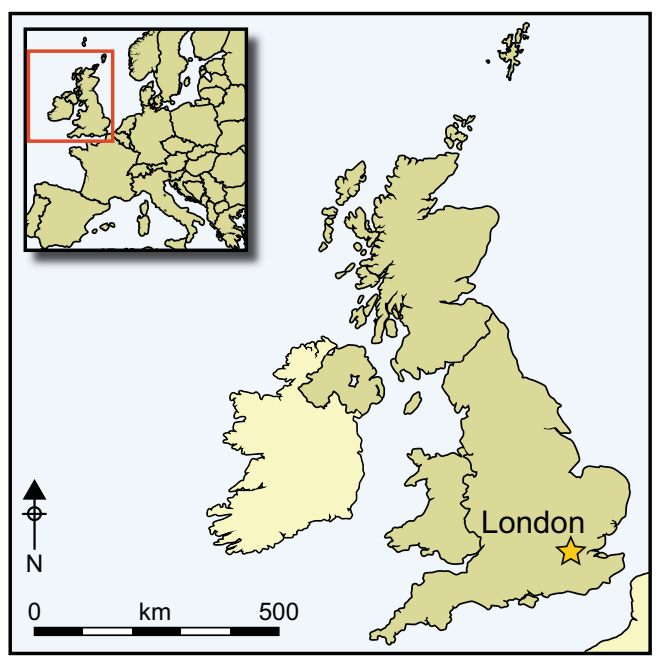

The appearance of the distinctive 'Beaker package marks an important horizon in British prehistory, but was it associated with immigrants to Britain or with indigenous converts? Analysis of the skeletal remains of 264 individuals from the British Chalcolithic-Early Bronze Age is revealing new information about the diet, migration and mobility of those buried with Beaker pottery and related material. Results indicate a considerable degree of mobility between childhood and death, but mostly within Britain rather than from Europe. Both migration and emulation appear to have had an important role in the adoption and spread of the Beaker package.

Keywords: Britain, Bronze Age, Beaker, migration, mobility, diet, Bayesian analysis, isotope analysis, osteology

UCL Institute of Archaeology, 31-34 Gordon Square, London WC1H OPY, UK

Faculty of Life Sciences, University of Manchester, Dover Street, Manchester M13 9PL, UK

Max Planck Institute for Evolutionary Anthropology, Deutscher Platz 6, 04103 Leipzig, Germany

Department of Archaeology, University of Durham, South Road, Durham DH1 3LE, UK

Department of Anthropology, University of British Columbia, 6303 NW Marine Drive, Vancouver, BC, V6T 1Z1, Canada

National Museums Scotland, Chambers Street, Edinburgh EH1 1JF, UK

University of Aberdeen Museums, High Street, Aberdeen AB24 3EN, UK

British Geological Survey, Keyworth, Nottingham NG12 5GG, UK

Department of Archaeological Sciences, University of Bradford, Bradford BD7 1DP, UK

School of Anthropology \& Conservation, University of Kent, Canterbury CT2 7NR, UK

Chronologies, 25 Onslow Road, Sheffield S11 7AF, UK

Langton Fold, North Lane, South Harting, West Sussex, GU31 5NW, UK

3 clo UCL Institute of Archaeology, 31-34 Gordon Square, London WC1H OPY, UK

${ }_{15}$ RLAHA, University of Oxford, Dyson Perrins Building, South Parks Road, Oxford OX1 3QY, UK

15 British Museum, Great Russell Street, London WC1B 3DG, UK 


\section{Introduction}

The 'Bell Beaker folk' have long been considered a prime example of migration in prehistory. During the third millennium BC, new pottery forms, new inhumation rites and unusual skeletal morphology (brachycephalic or broad-headed skulls) appeared across much of Western Europe. In the late 1970s, at the height of processualist reaction against migrationbased explanations, this archaeological 'culture' was newly interpreted as the diffusion of a cult package (Burgess \& Shennan 1976). Yet the case for migration of Beaker-using people to the British Isles remained firmly supported (e.g. Waddell 1978).

Within continental Europe, recent research into non-metric dental morphological traits (Desideri \& Besse 2010) and strontium isotope analysis of tooth enamel (Price et al. 2004) has shifted the focus back to Beaker users as migrant groups, demonstrating the arrival of incoming populations at the end of the Neolithic into parts of Switzerland, Bavaria, Austria, the Czech Republic and Hungary. Recent analyses of ancient DNA are providing further support for Bell Beaker migrations within continental Europe (Allentoft et al. 2015; Haak et al. 2015; Hervella et al. 2015).

The debate about the arrival of the Beaker package in Britain was revived in 2002 by the discovery of the Amesbury Archer, buried near Stonehenge in 2380-2290 cal BC (95\% probability; OxA-13541; Barclay et al. 2011: fig. 58). From the oxygen isotope ratios for his tooth enamel, he was probably a long-distance migrant from continental Europe (Chenery \& Evans 2011). But how typical was his pattern of lifetime mobility for the wider population of Britain during the Chalcolithic-Early Bronze Age?

The skeletal remains of 264 individuals buried in Britain (Figure 1) in that period (c. 2500 BC-1500 cal BC) have been analysed, as part of the Beaker People Project (BPP), for isotope ratios (strontium, oxygen, sulphur, nitrogen and carbon), radiocarbon dating, osteology and dental microwear (Parker Pearson et al. forthcoming). The sample ranged from the north of mainland Scotland to the Wessex heartland of southern England, and included the Beakers $\&$ Bodies Project in north-eastern Scotland (Curtis \& Wilkin 2012). The BPP is the first large-scale strontium and oxygen isotope investigation of human skeletons excavated from across Britain, aiming to establish whether the Bell Beaker people were immigrant groups (Childe 1929: 194-96) or indigenous converts to a 'Beaker package' of cult practices and prestige goods (Burgess \& Shennan 1976).

\section{Chronology}

The earliest dates for Bell Beakers, in the second quarter of the third millennium BC, occur in Iberia and southern France (Müller \& van Willigen 2001). Yet across much of Europe, the Bell Beaker phenomenon was not present until the middle of that millennium, reaching Britain relatively late, with no cases dateable to before $2500 \mathrm{BC}$.

For the BPP, a Bayesian approach, using 193 new radiocarbon dates with existing dates from a further 82 burials, was adopted for the interpretation of the period of use of Beakers in graves. This assumes that dates are uniformly distributed across the time period (Buck et al. 1992, 1996; Bayliss et al. 2007). Although this use of a uniform distribution is far from ideal-especially if Bell Beakers originated at a given time in a given place, were gradually 


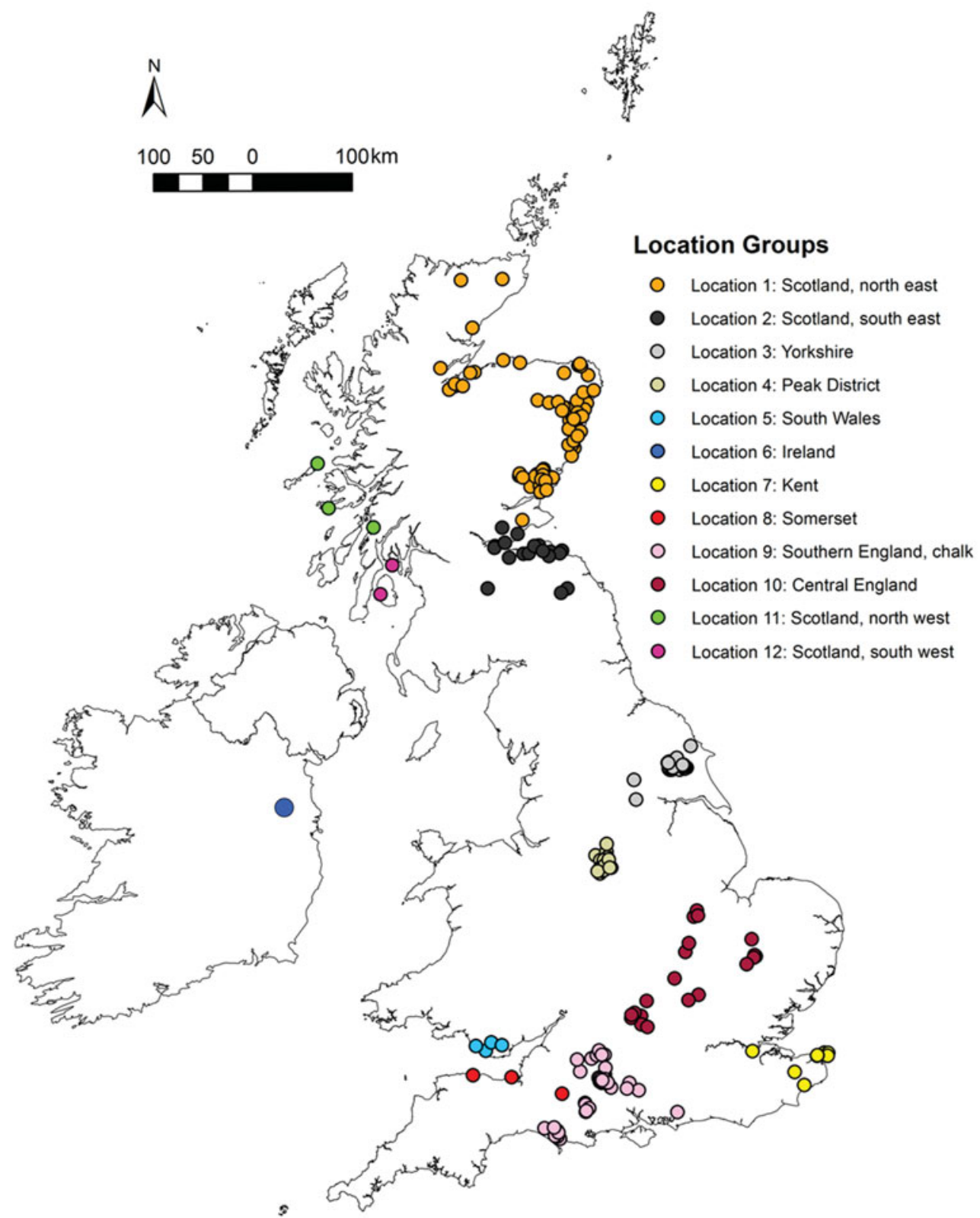

Figure 1. Beaker-period burials in Britain for which isotopic analysis has been undertaken.

produced in greater numbers and then decreased as their popularity waned-it makes the fewest assumptions about the distribution of dates.

The model estimates the first use in Britain of Bell Beakers in burials to have occurred in 2475-2360 cal BC (95\% probability) and probably 2450-2385 cal BC (68\% probability). Their first use in funerary contexts started in Wessex (84\% probability), followed by the Peak (C) Antiquity Publications Ltd, 2016 
a)
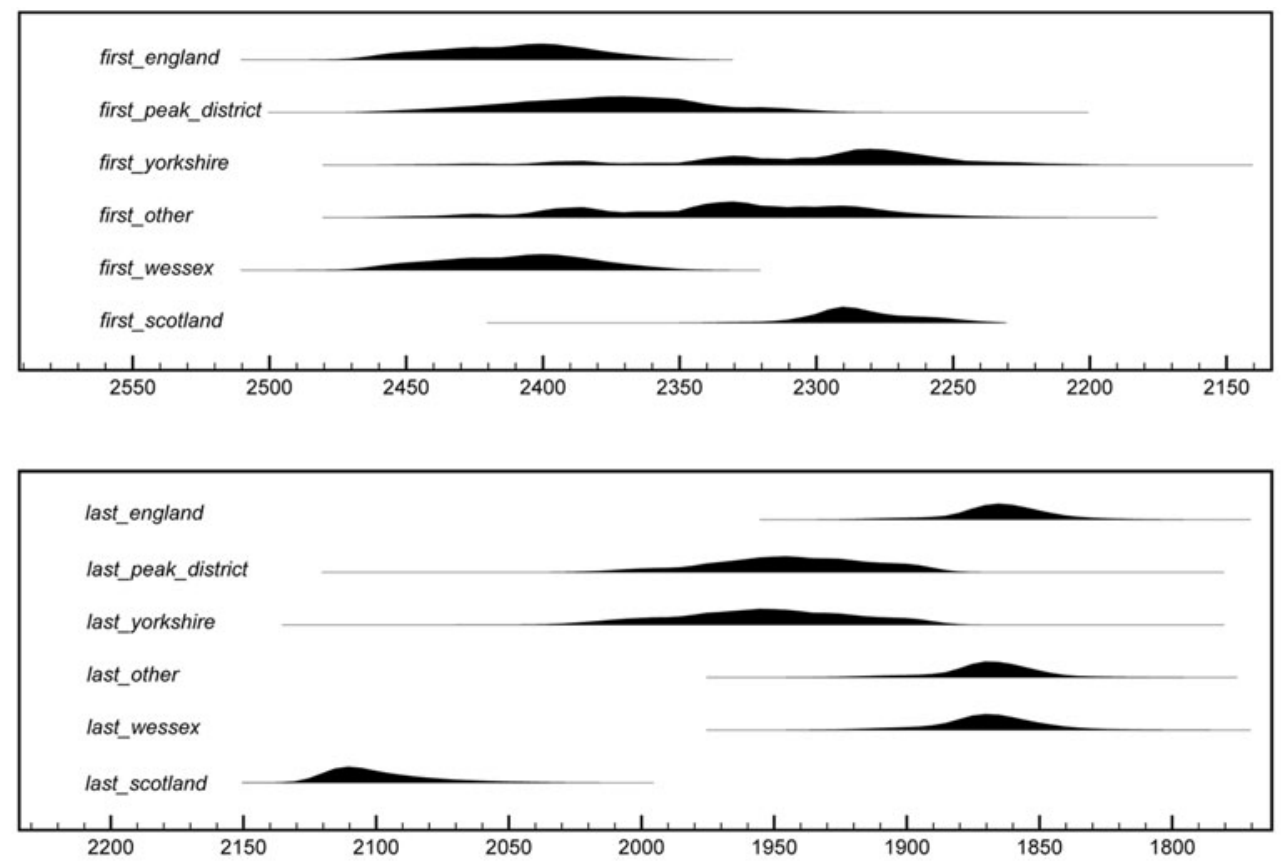

b)

Posterior Density Estimate (cal BC)

Figure 2. Probability distributions for use of Beakers in burials in geographic regions of Britain: a) beginning of use; b) end of use.

District (61\% probability), Scotland (47\% probability), other regions (44\% probability) and finally Yorkshire (36\% probability; Figure 2).

The end of use of Beakers in burials in Britain is estimated to have occurred in 19051810 cal BC (95\% probability) and probably $1880-1840$ cal BC (68\% probability). Their last use in graves in Scotland occurred earlier, in 2130-2045 cal BC (95\% probability) or 2120-2080 cal BC (68\% probability).

Beakers first stopped being placed in burials in Scotland (100\% probability), then Yorkshire (58\%), the Peak District (58\%), other areas (49\%) and finally Wessex (49\% probability; Figure 2). The overall period of use of Beakers as grave goods is estimated to have been $480-640$ years ( $95 \%$ probability) and probably $515-600$ years (68\% probability). In northern Britain, Food Vessels (a wholly British and Irish style of post- and late-Beaker pottery; Wilkin 2014) replaced Beakers, whereas Beakers continued to be used in Wessex long after the introduction of Food Vessels in that region.

British Beaker burials have been divided into three chronological stages (Figure 3; Needham 2005, 2007, 2012), a scheme supported by the new radiocarbon dates (with two exceptions that could be explained by curated bodies with anachronistic grave goods; see Booth et al. 2015). The earliest period (c. 2450/2400-2300 cal BC) is characterised by Low-Carinated Bell Beakers, while non-perishable grave goods include copper knives, stone wristguards, barbed-and-tanged flint arrowheads, flint tools and flakes, boars' tusks, bone 


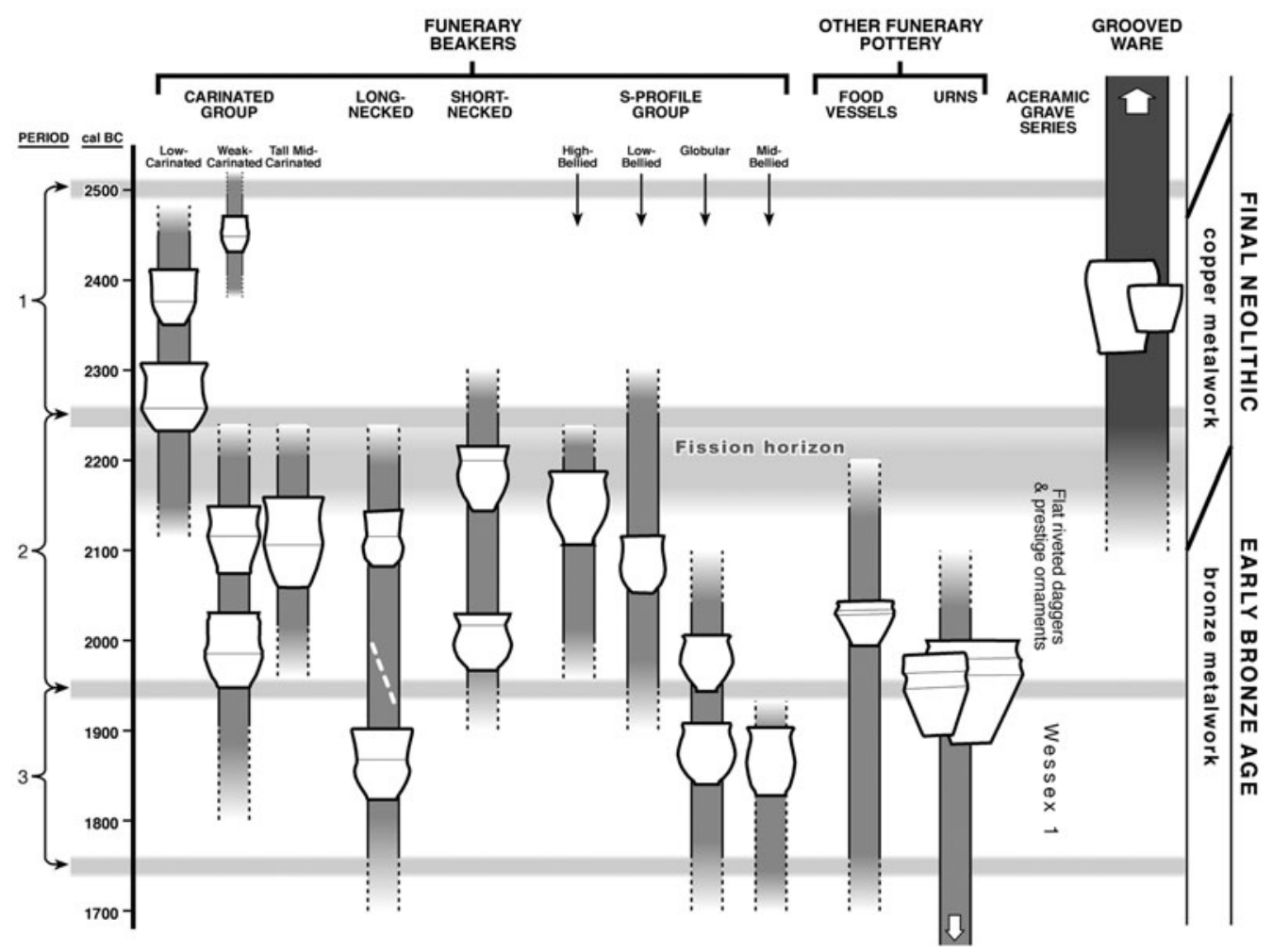

Figure 3. The ceramic chronology for British Beakers.

pins, antler or bone spatulae, belt rings, iron pyrites strike-a-lights, gold hair-tress rings and other ornaments, such as those accompanying the Amesbury Archer (Fitzpatrick 2011).

The second period begins around 2300/2250 cal BC with a 'fission horizon' (Needham 2005), when a wide range of pot styles was adopted for funerary use. From this point onwards, these British pots are known simply as 'Beakers' to distinguish them from the earlier, pan-European style of Bell Beaker. Copper was succeeded around 2200/2150 BC by bronze. Needham's third period (c. 1950-1810 cal BC) equates with Wessex I, the horizon of gold-provisioned burials (both inhumations and cremations) of Britain's Early Bronze Age (Piggott 1938; Needham et al. 2010).

\section{Human osteology}

The selection of skeletal remains was dictated by the presence of suitable dental enamel, so the sample is not entirely representative of the archaeologically retrieved population. There is a deliberate bias in avoiding the very young (whose permanent teeth were insufficiently developed) and the elderly (whose molars were missing or severely worn). Slightly more male skeletons are present than female or those of unknown sex, and there are more middle-aged adults than those of other ages. Examples of trauma were few; none were as dramatic as the chronic infection in the Amesbury Archer's left knee (McKinley 2011: 80-81).

(C) Antiquity Publications Ltd, 2016 
Statistical analyses of the Peak District sample reveal significant differences in cranial length between Early Neolithic (c. 3800-3400 cal BC) and Beaker/Bronze Age (c. 2500$1500 \mathrm{cal} \mathrm{BC}$ ) individuals, confirming the transition from dolichocephalic (long-headed) to brachycephalic cranial forms. Certain individual skulls exhibit occipital flattening, probably caused by infants lying flat on their backs or being secured to a cradle-board. Two Neolithic skulls exhibit artificial cranial deformation resulting from infant head-binding to produce long skulls. This evidence was recognised at the time of excavation (Bateman 1861; Wilson 1863: 273-74) but has been largely forgotten; it goes some way to resolving the debate about 'racial types' of brachycephalic Beaker people and dolichocephalic Neolithic people across Europe (Childe 1925: 90; Gerhardt 1976; Brodie 1994) by introducing a cultural explanation for some of these differences in cranial shape.

\section{Carbon, nitrogen and sulphur isotopes: diet and mobility}

Isotope ratios from skeletal collagen provide useful insights into diet but, as part of a multiisotope study of both bone and dentine to provide evidence for lifetime changes, they can also contribute to investigating mobility. Collagen chemistry reflects dietary protein, ultimately leading back to plants at the base of the food chain, which themselves reflect the isotope ratios found in their natural environment (e.g. atmospheric carbon, soil nitrogen, geological sulphur). This is similar to the way in which strontium and oxygen isotope ratios are used as evidence for mobility, although regional environmental distinctions are less clear.

The carbon isotope ratios reveal a restricted range of values that suggests both a consistent background environmental signal across Britain, and a consistent diet across the entire group, with no noticeable variation from northern Scotland to southern England (Jay \& Richards 2007; Jay et al. 2012). By contrast, dental microwear analysis (Mahoney 2007) reveals consistent regional differences in the physical properties of the foods consumed. Samples from central and southern England had a harder diet-foods requiring greater compressive forces, such as seeds or nuts-compared with more northern regions in England and Scotland, where a softer but still abrasive diet — consistent with greater dietary emphasis on plants and their contaminants-was consumed.

No individuals from the period $c .2500-1500 \mathrm{cal} \mathrm{BC}$ had a significant marine component in their diet, despite the fact that many of the burial sites are very close to the coast. In general, Beaker people were omnivores, with a relatively high level of animal protein in their diet.

This is an unprecedented dataset of carbon and nitrogen isotopes at the British scale with a consistent analytical foundation, and no regional distinctions in human diet have been found, suggesting that climate differences within Britain had little effect on regional dietary resource values at this time. Since temperature and rainfall have an effect at the continental scale (e.g. van Klinken et al. 1994), the consistency of the $\delta^{13} \mathrm{C}$ data for both bone and dentine may indicate that mobility revealed by other isotope ratios (see below) relates largely to movement within Britain, and not at a continental scale.

The BPP analyses were of collagen from both bone and tooth root dentine for each individual. Bone remodels during life and thus reflects an averaged lifetime dietary input, albeit weighted towards adolescence. The tooth root results reflect only childhood diet 
because primary dentine forms early and is not remodelled. Although secondary and tertiary dentine can form during life in the pulp chamber, the amounts involved are slight. Given that the BPP processed entire roots (in order to produce enough collagen for sulphur analysis) the homogenised bulk product from each tooth is unlikely to have produced an isotope ratio significantly affected by dentine that formed after childhood. All collagen data retained for interpretation, from both bone and dentine, fell within the quality parameters that are usually considered indicative of samples free from contamination or diagenetic alteration (van Klinken 1999).

The average carbon isotope values are $-21.2 \pm 0.3 \%$ for bone, and $-21.0 \pm 0.4 \%$ for dentine. The $\delta^{15} \mathrm{~N}$ ratios show more variation than the carbon isotope ratios $(10.2 \pm 0.6 \%$ for bone; $10.3 \pm 0.7 \%$ for dentine), most probably reflecting local environments rather than differences in diet; there is a broad distinction between those individuals buried on chalk bedrock and those buried west of the chalk $\left(\delta^{15} \mathrm{~N}\right.$ ratios of $10.0 \pm 0.7 \%$ for Cretaceous and young terrains to the east versus $10.4 \pm 0.5 \%$ for older terrains to the west). This distinction is also present for domesticated herbivores $(5.6 \pm 0.6 \%, n=58$, as opposed to $6.2 \pm 0.5 \%, n=32$ ). Among those individuals with unusual $\delta^{13} \mathrm{C}$ and $\delta^{15} \mathrm{~N}$ values are two from Kent (Figure 4); these values may indicate migration from outside Britain or merely non-normative dietary histories.

Across the dataset, $\delta^{13} \mathrm{C}$ and $\delta^{15} \mathrm{~N}$ values are slightly higher for dentine than for bone (by $0.2 \pm 0.3 \%$ for carbon and $0.2 \pm 0.5 \%$ o for nitrogen). The majority of teeth analysed were second molars or premolars, chosen specifically to avoid the probable period for breastfeeding, so the difference is unlikely to have been caused by breastmilk. It is possible that there is a physiological cause for this systematic difference, but childhood diet in this overall population may have differed from that of adults in a consistent way across Britain at this time.

Extreme ( $>3$ standard deviations (SD) from the mean) carbon and nitrogen isotope ratio differences between bone and dentine in nine individuals, from sites across Britain, may reflect migration between childhood and later-life environments, as supported in several cases by the other isotope data. For example, one of the Boscombe Bowmen from a multiple burial in Wessex (Fitzpatrick 2011) has a $\Delta{ }^{13} \mathrm{C}_{\text {(bone-dentine) }}$ value of $0.9 \%$ (Figure 5). His strontium and oxygen isotope ratios have been interpreted as being indicative of migration, possibly from Wales (Evans et al. 2006). The bone-dentine difference may therefore indicate mobility.

Detailed results of the sulphur isotope analysis are presented elsewhere (see Jay et al. 2012: 233-34; Parker Pearson et al. forthcoming). Regional variation in collagen $\delta^{34} S$ does occur, probably caused mainly by geology and distance from the coast, but also possibly by dietary differences. While carbon and nitrogen isotope ratios reveal no dietary difference between northern and southern Britain of the kind revealed by dental microwear, there are regional $\delta^{34} S$ distinctions. References to $\delta^{34} S$ ratios are made below for cases of interest.

\section{Strontium and oxygen isotopes}

Enamel strontium isotope ratios are a weighted average produced from diet over many months (Montgomery et al. 2010). It is often impossible, therefore, to identify the different

(C) Antiquity Publications Ltd, 2016 


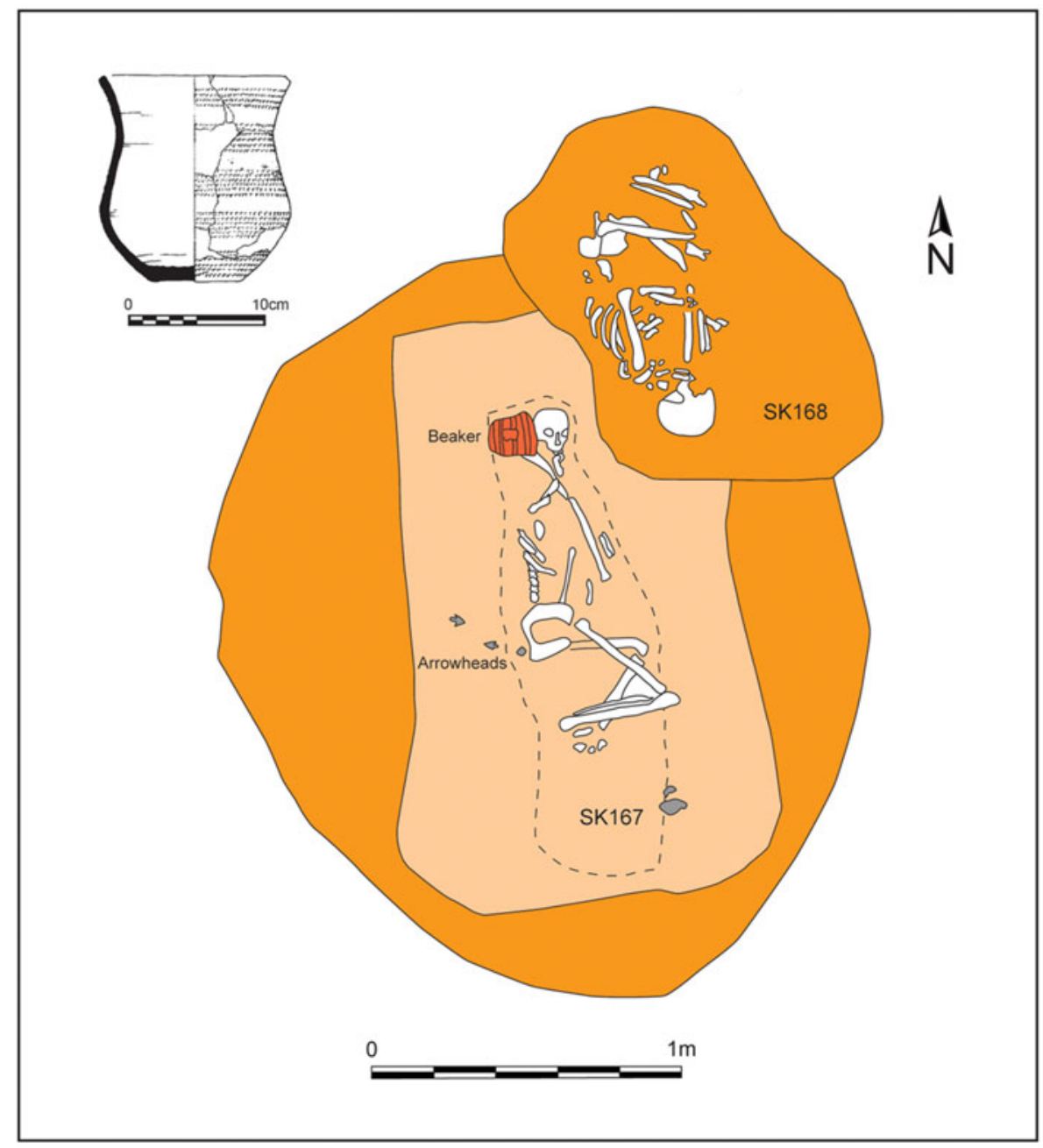

Figure 4. Two burials from the QEQM Hospital site, Margate. The earlier, male burial (SK167 with a Beaker and three arrowheads) has the highest $\delta^{15} \mathrm{~N}$ ratio (at 11.9\%o) within the dataset, and the female burial (SK168 with an arrowhead) has the most negative ${ }^{13} \mathrm{C}(-22.3 \%$ ). SK167 dates to 2330-2195 cal BC (94\% probability; Wk-18733) and SK168 to 2140-1955 cal BC (95\% probability; OxA-V-2271-37). Drawing by Irene De Luis after Moody (2008).

contributions and, if food is procured locally from two or more rock types, the resulting human isotope ratio may not be characteristic of either (Montgomery 2010). Such difficulties were largely overcome by the BPP because the majority of individuals were excavated from geographically restricted, well-characterised regions of chalk and limestone (Figure 6). For Scotland, however, individuals were sampled from a wide range of geological terrains, many having no comparative data from either the local biosphere or other archaeological skeletons. It has therefore not been possible to constrain local ranges for the Scottish burials as tightly as regions within England. 


\section{$\Delta{ }^{13} C_{\text {(bone) }}(\% \circ)$}

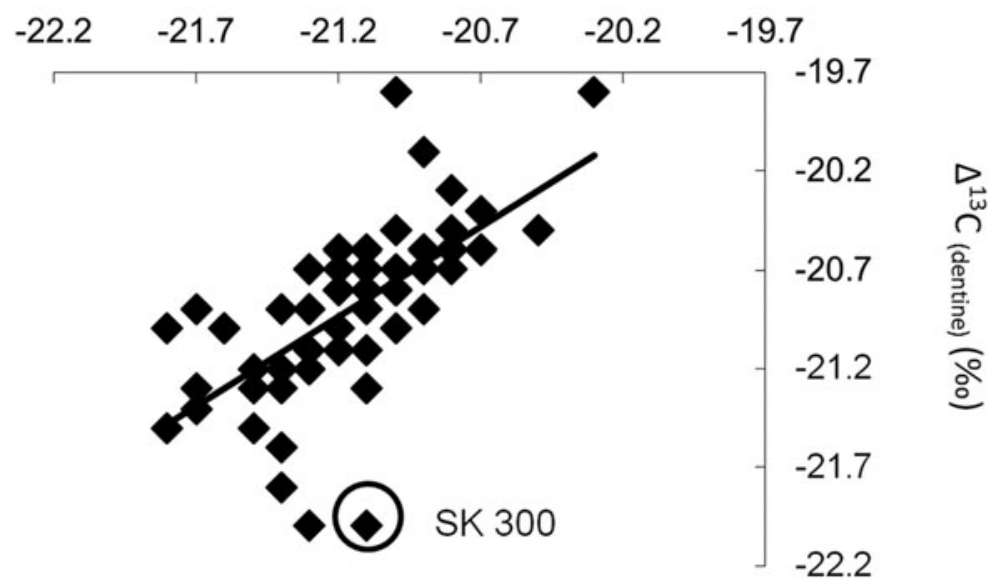

Figure 5. $\delta^{13} C$ values from bone and dentine ( $x$ and $y$ axes respectively) for individuals from southern England, with a 'Boscombe Bowman' (SK300) highlighted as having a difference between the values for the two skeletal fractions that is more than $3 S D$ from the mean of such differences.

Individual mobility has, however, been indicated for many of the individuals from Scotland by analysing dentine mineral (not to be confused with the collagen discussed above), which is not resistant to diagenetic strontium changes caused by the burial environment, as is the enamel. The strontium isotope ratio of the dentine can provide an indication of the trend towards the values of the burial soil and, hence, the local geology (Montgomery et al. 2007). The comparison between the unaltered enamel value and that from the dentine, which is equalising with the burial environment, can suggest whether the enamel shows a probable non-local signal even if the geological ranges for Scotland are not tightly constrained.

Few age-related or gender differences in mobility have been revealed by strontium isotope analysis. The proportion of females to males among 'movers' is slightly higher than that in the entire sampled population.

The proportion of detected probable lifetime migrants in the sample is $28 \%$ on strontium isotope analysis alone (Table 1). The real figure is probably higher as those who moved between similar geological regions will generally have remained undetected, and this table only includes migrants with a $\mathrm{Sr}$ isotope difference of $>0.001$ between the enamel value and the environmental value, the latter being based either on measured dentine analysis (this study) or taken from Evans et al. (2012). The isotope data may even relate to longdistance corpse transport as well as lifetime mobility. On the strontium isotope evidence, the proportion of movers is $28 \%$; this increases to $41 \%$ when results from other isotopic analyses are included (Table 1).

There are also considerable differences between regions, with the highest mobility in northern Scotland, Yorkshire and the Peak District. It should be noted, however, that the complex geology of Scotland produces significant changes in biosphere strontium isotopes at a relatively small geographic scale, so, while identified as non-local, movements in those (C) Antiquity Publications Ltd, 2016 
Table 1. Numbers of individuals (c. 2500-1500 cal BC) analysed by region and by broad period, showing those detected as probable 'non-locals' by ${ }^{87} \mathrm{Sr} /{ }^{86} \mathrm{Sr}$ isotope analysis and other isotopic evidence.

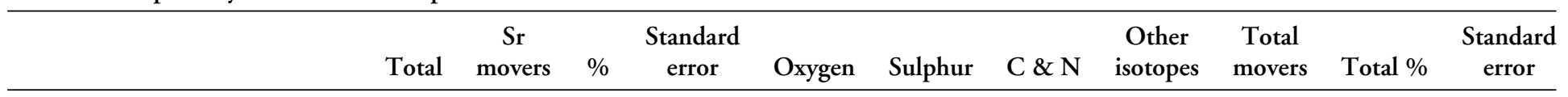

Northern Scotland

Southern Scotland

$\begin{array}{cccc}27 & 17 & 63 & 9 \\ 13 & 3 & 23 & 12 \\ 4 & 2 & 50 & 25 \\ 68 & 13 & 19 & 5 \\ 29 & 15 & 52 & 9 \\ 5 & 1 & 20 & 18 \\ 17 & 6 & 35 & 12 \\ 3 & 1 & 33 & 27 \\ 68 & 16 & 23 & 5 \\ 30 & 1 & 3 & 3 \\ \mathbf{2 6 4} & \mathbf{7 5} & \mathbf{2 8} & \mathbf{3} \\ 32 & 10 & 31 & 8\end{array}$

Yorkshire

Peak District

Wales

Kent

Somerset

Southern England

Central England

Total

Earlier Chalcolithic

c. 2450-2300 cal BC

Later Chalcolithic

c. $2300-2150 \mathrm{cal} \mathrm{BC}$

arly Bronze Age

c. $2150-1500 \mathrm{cal} \mathrm{BC}$

$\begin{array}{lll}111 & 37 & 33\end{array}$

5

4

$10 \quad 2$

16

$53 \quad 48$

5

Undated burials with a Beaker

20

Undated burials without a Beaker

42

$\begin{array}{ll}5 & 25 \\ 4 & 10\end{array}$

5

1

3

0

0

2
4

7
8

35

19

11

6 

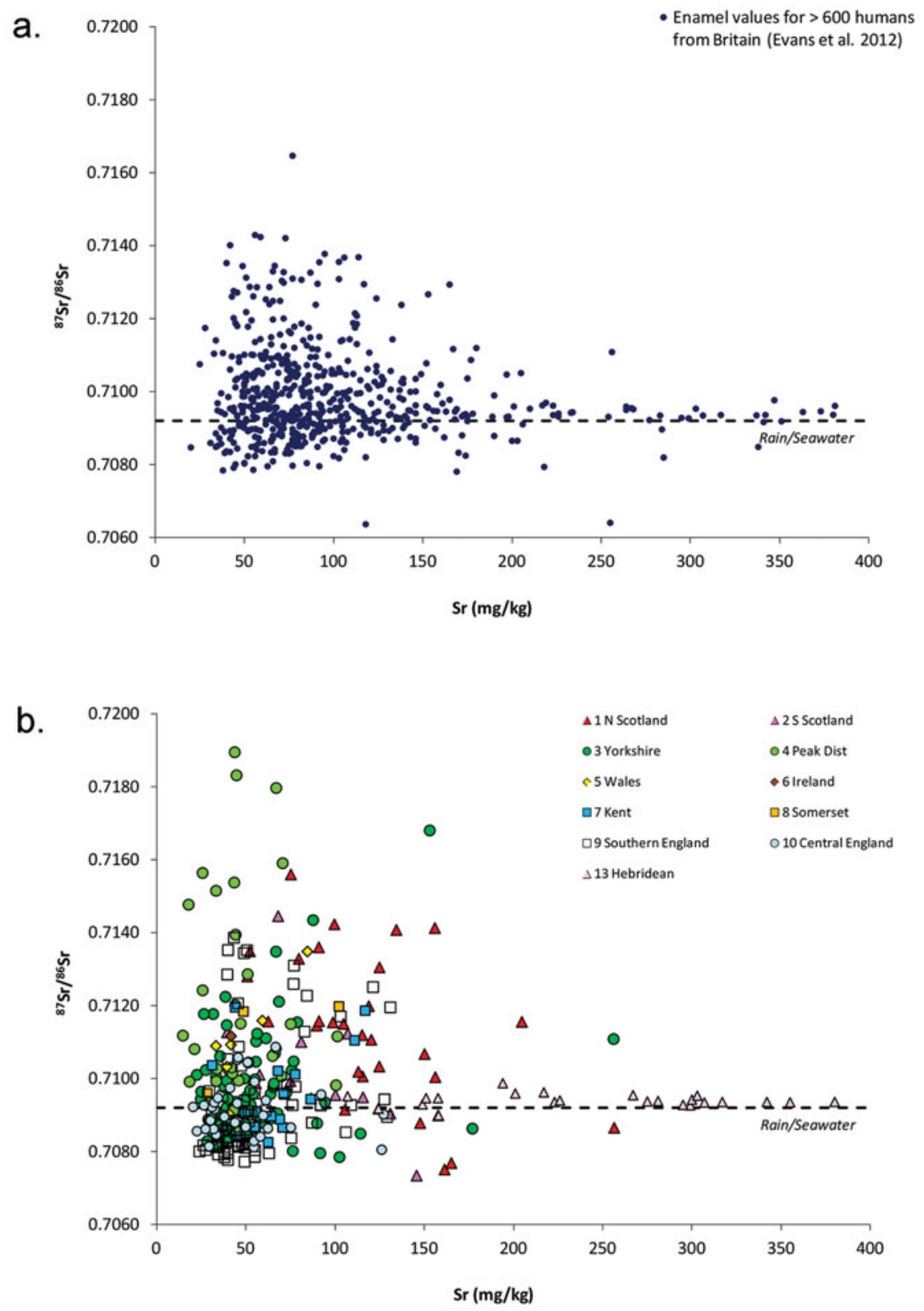

Figure 6. a) All the enamel strontium data for Britain from non-BPP archaeological investigations of all periods ( $n>600$; Evans et al. 2012); b) all the enamel strontium data for Britain from the BPP $(n=264)$, grouped by region.

instances may not necessarily have covered large distances. The English Midlands displayed the least mobility, with strontium isotope results consistent with the Cretaceous and Jurassic geology of places of burial in all but one instance. As many as nine individuals out of thirty in this region may, however, have been mobile on the basis of $\delta^{34} S$ and other isotopic evidence. One of these, a secondary burial from Irthlingborough, Northamptonshire (C) Antiquity Publications Ltd, 2016 
(Figure 7), has sufficiently extreme differences between bone and dentine $\delta^{34} S, \delta^{15} \mathrm{~N}$ and $\delta^{15} \mathrm{C}$ values to suggest that he grew up some distance from where he was buried.

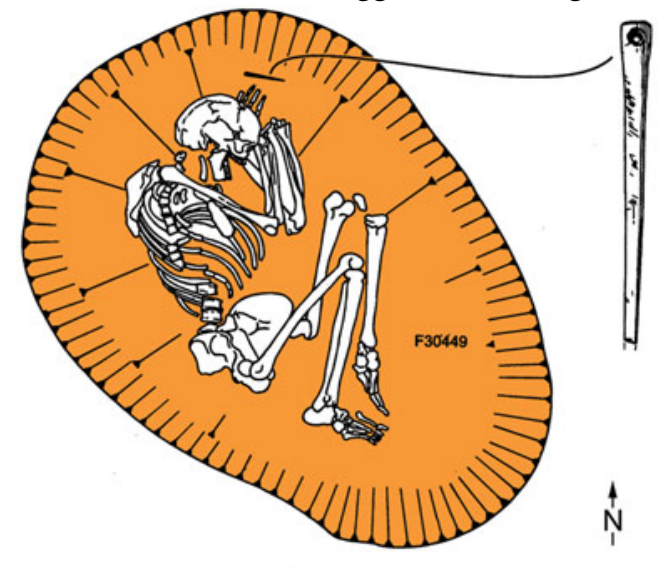

0

Figure 7. A secondary burial (1945-1730 cal BC [95\% probability; UB-3147]) into the top of a round barrow at Irthlingborough, Northamptonshire, is that of a young man with a bone pin. Extreme divergences between bone and dentine $\delta^{34} S, \delta^{15} \mathrm{~N}$ and $\delta^{15} \mathrm{C}$ ratios indicate probable migration after childhood. (From Harding \& Healy 2007.)

Regional differences: the Peak District and Wessex

The Peak District produced unusually high strontium isotope ratios $(>0.7145)$ for eight individuals, of both sexes. Extremely rare in any European population outside Scandinavia, these high ratios are produced by the consumption of crops grown on ancient or granitic rocks. Another Peak District individual is a middle-aged man with childhood cranial modification from Bee Low (Figure 8), buried in a round barrow with a bronze pin and two possible awls but no pot, in 2200-2030 cal BC (95\% probability; SUERC-31855). Although his strontium isotope ratio is not unusual for the Peak District, his extremely low oxygen isotope $\left(\delta^{18} \mathrm{O}\right)$ value of $16.2 \%$ is equivalent to that of the Amesbury Archer (Chenery \& Evans 2011), indicating that the Bee Low man grew up in a cold and 'continental' climate, either in eastern Scotland or outside Britain. His unusually high $\Delta^{34} S_{\text {(bone-dentine) value }}(8.5 \%$ ) suggests migration from a region farther from the coast than the Peak District, i.e. continental Europe.

Similarly low $\delta^{18} \mathrm{O}$ values $(16.2 \%$ ) were obtained from only two other burials, both from eastern Scotland; overall isotopic results suggest that they are probably indigenous to that region. The long-distance mobility of the Amesbury Archer (and Bee Low man) is the exception rather than the norm.

Ten individuals in Wessex (both male and female, buried with and without Beakers) have strontium isotope ratios between around 0.7120 and 0.7140 (Figure 9). These include three of the 'Boscombe Bowmen' (Evans \& Chenery 2011). Such values derive from Palaeozoic rocks (e.g. Devonian sandstone or Silurian mudstones) or from a combination of atmospheric deposition (e.g. rainfall) and granitic or gneissic bedrock; they cannot be obtained from the chalk or from adjacent Mesozoic and Cenozoic sediments. This suggests a migration stream into Wessex from the west or north, or from beyond the shores of Britain (Ireland or the Continent). The wide range of $\delta^{18} \mathrm{O}$ values (16.9\%o-19.3\%o) amongst this group makes it unlikely that they derive from a single place.

\section{Conclusion}

Brodie $(1994,2001)$ proposed that the Beaker way of life spread through exchange of marriage partners. Vander Linden $(2006,2007)$ emphasises that Bell Beaker migration was 

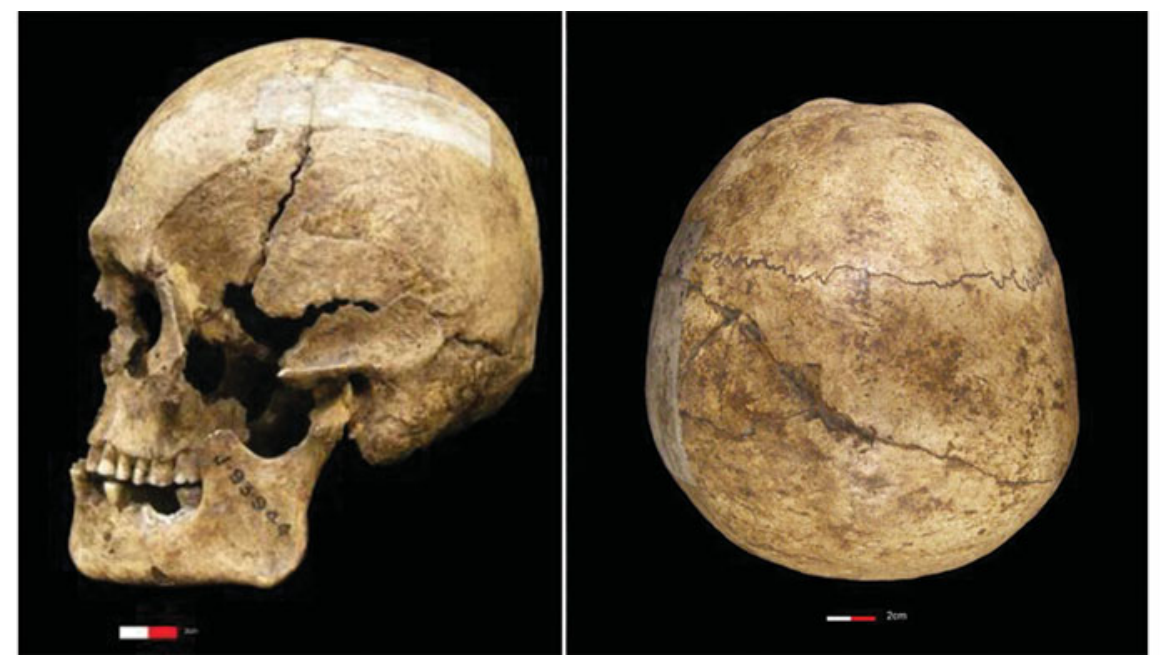

Figure 8. The skull from Bee Low, Derbyshire (SK200; J.93.944), demonstrating occipital flattening in two views: taken in norma lateralis (left) and norma verticalis (right). Image courtesy of Sheffield City Museum.

not an all-pervasive wave of advance. He suggests a generalised marriage exchange model (as opposed to restricted, Lévi-Strauss 1969), in which partners marry out of the group without expectation of counter-marriage; in this way, Beaker know-how and ideas could have moved long distances, producing the characteristic fragmented geographic distributions. Needham (2005, 2007) uses aspects of this approach to explain the pioneering phase of Beaker dispersal but disputes Brodie's proposed mode of inter-marriage. Instead, expansion led to inter-cultural contact in a reinforcing circle: if the indigenous response was favourable, then Beaker groups consolidated and further expanded, with a continuous process of buddingoff. Our results show little difference between male and female migration histories across Britain: notions of exogamous exchange of female marriage partners do not explain the observed patterns of movement.

Our research demonstrates a considerable degree of mobility between childhood and death, most of it probably within Britain and persisting over many centuries. The strontium isotope results show that almost a third of the sampled population were buried in a geological region different to that in which they grew up. Some regions, notably the Peak District, show considerable evidence for inward migration, while others, e.g. central England, show virtually none.

For Bell Beaker people in Central Europe, the proportion of migrants into local populations is estimated variously as $62 \%$ or $24 \%$, depending on the method of determination (Price et al. 2004: 30). These movements are considered to have taken place throughout the Bell Beaker period, and involved either small groups or individuals (Grupe et al. 1997, 1999, 2001; Price et al. 1994, 1998, 2004). The more conservative estimate of $24 \%$ is based on cases where tooth enamel strontium isotope values differ from bone or burial environment by $>0.001$.

We consider that most lifetime movement during the Chalcolithic-Early Bronze Age was within Britain rather than from Europe into Britain. For a few examples, including (C) Antiquity Publications Ltd, 2016 


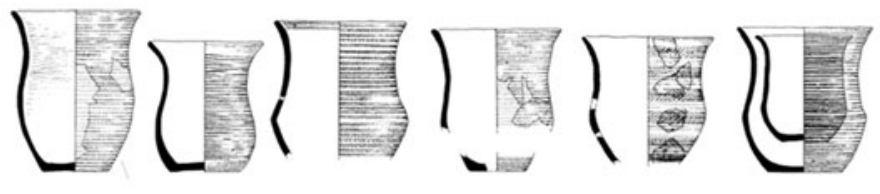

SK300, SK302, SK303 The Boscombe Bowmen

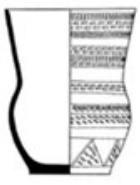
SK135 Netheravon 1
2290.2125 cal $B C$
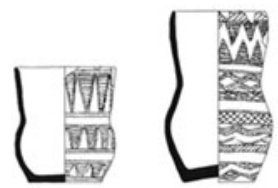

SK182 Rimbury
2145-1955 cal BC
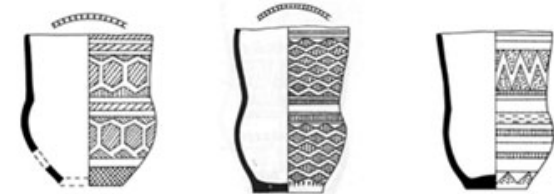

SK184 Bradford Peverell
$2065-1010$ cal BC

SK281 Wilsford Down long barrow SK 282 Winterbourne Stoke
$2200-2020$ cal BC

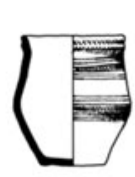

SK150 Llandow

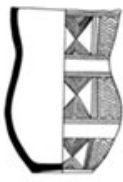

SK151 Llanharry 2200-2040 BC

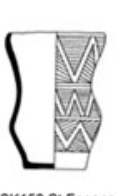

SK152 St Fagans

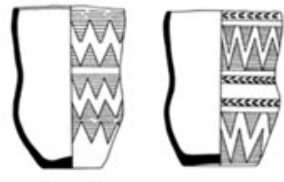

SK154 \& SK155 Merthyr Mawr C1 \& C3 2130-1900 BC

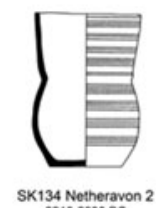

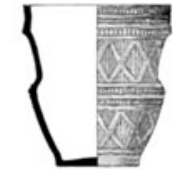

SK142 Shrewton 5e $2200-1900$ BC

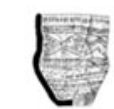
SK144 Shrowton G24

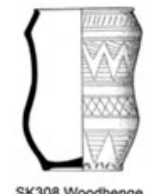

SK308 Woodhenge

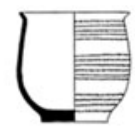

SK307 The Sanctuar 2450-2280 cal BC

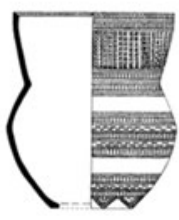

SK 159 Wincanton

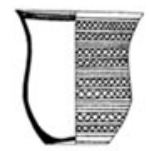

SK160 Stogursey

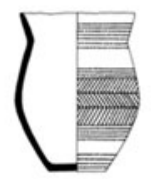

SK161 Culbone Hill
$2490-2200 \mathrm{BC}$

Figure 9. Top two rows: Beakers associated with nine of the ten individuals from Wessex whose strontium isotope ratios indicate that they grew up some distance away from Wessex on Devonian/Silurian geology. Third row: Beakers in burials of non-migrants on South Wales Silurian geology. Fourth row: Beakers in burials of non-migrants on Wessex chalk. Fifth row: Beakers in burials of non-migrants on Devonian geology of south-west England. The second, third and fourth rows include Long-Necked Beakers sharing Clarke's Southern British motif group 4 (1970: 427). (From Clarke 1970; Woodward 1980; Fitzpatrick 2011.) 
the Amesbury Archer, migration from the European Continent is the most probable explanation, and such migrations occurred at different times during the period, not simply at its beginning. Acknowledging that isotopic analyses may identify only first-generation migrants, the consistent proportion of non-locals through time indicates a high, sustained degree of mobility, much of it multi-directional and much of it probably linked to mobile subsistence practices. Rather than positing mass migration as the only process of Beaker expansion, we suspect that cultural transmission (diffusion of a 'Beaker package', as proposed by Burgess \& Shennan (1976)) was also significant, especially in regions such as the English Midlands. This process of cultural transmission has been characterised as "emulation of what may increasingly have seemed to be a preferable way of life because of the advantages it brought" (Needham 2007: 44), accompanying the acceleration in growth of Beaker communities in the Later Chalcolithic (Needham 2012: 20-23, fig. 1.3).

The isotopic results provide a further dimension to previous studies of osteology and material culture, indicating that mobility was pervasive, regionally variable and long term during the British Chalcolithic and Early Bronze Age. It is probable that these isotope data will soon be enhanced by those of ancient DNA for Britain, allowing us to assess the strength of our conclusion that both migration and emulation-rather than migration alone-were significant processes behind the Bell Beaker phenomenon in Britain and elsewhere.

\section{Acknowledgements}

This project was made possible by many curators and institutions throughout the UK and Ireland, too numerous to mention here, who allowed sampling of bones and teeth. The Beaker People Project was funded by the AHRC (grant 19382), and the Beakers \& Bodies Project by the Leverhulme Trust (grant F/00152/S).

\section{References}

Allentoft, M.E., M. Sikora, K.-G. Sjogren, S. Rasmussen, M. Rasmussen, J. STENDERUP, P.B. Damgaard, H. Schroeder, T. Ahlström, L. Vinner, A.-S. Malaspinas, A. Margaryan, T.F.G. Higham, D. Chivall, N. LYNNERUP, L. Harvig, J. Baron, P.D. Casa, P. Dąbrowski, P.R. Duffy, A.V. Ebel, A. EPIMAKHOV, K. FreI, M. FurmaneK, T. Gralak, A. Gromov, S. Gronkiewicz, G. Grupe, T. Hajdu, R. Jarysz, V. Khartanovich, A. KhOKhlov, V. Kiss, J. KOLAR, A. KRIISKa, I. LASAK, C. LONGHI, G. McGlynn, A. Merkevicius, I. Merkyte, M. Metspalu, R. Mkrtchyan, V. Moiseyev, L. Paja, G. Palfi, D. Pokutta, L. Pospieszny, T.D. Price, L. SaAG, M. Sablin, N. Shishlina, V. SMrcka, V.I. Soenov, V. SZEVERENyI, G. Toth, S.V. TRIFANOVA, L. VARUL, M. Vicze, L. YePISKOPOSYAN, V. ZHITENEV, L. ORLANDO, T. Sicheritz-Ponten, S. Brunak, R. Nielsen, K. KRistiansen \& E. WillersleV. 2015. Population genomics of Bronze Age Eurasia. Nature 522: 167-72. http://dx.doi.org/10.1038/ nature 14507
Barclay, A. \& P. Marshall, with T.F.G. Higham. 2011. Chronology and the radiocarbon dating programme, in A.P. Fitzpatrick The Amesbury Archer and the Boscombe Bowmen: Bell Beaker burials at Boscombe Down, Amesbury, Wiltshire (Wessex Archeology 27): 167-84. Salisbury: Wessex Archaeology.

Bateman, T. 1861. Ten years' diggings in Celtic and Saxon grave hills in the counties of Derby, Stafford and York, from 1848 to 1858: with notices of some former discoveries hitherto unpublished, and remarks on the crania and pottery from the mounds. London: George Allen \& Sons.

Bayliss, A., C. Bronk Ramsey, J. van der Plicht \& A. WhitTle. 2007. Bradshaw and Bayes: towards a timetable for the Neolithic. Cambridge Archaeological Journal 17(S1): 1-28. http://dx.doi.org/10.1017/S0959774307000145

Booth, T., A. Chamberlain \& M. Parker Pearson. 2015. Mummification in Bronze Age Britain. Antiquity 89: 1155-73. http://dx.doi.org/10.15184/aqy.2015.111 


\section{Beaker people in Britain}

Brodie, N. 1994. The Neolithic-Bronze Age transition in Britain: a critical review of some archaeological and craniological concepts (British Archaeological Reports British series 238). Oxford: British Archaeological Reports.

- 2001. Technological frontiers and the emergence of the Beaker Culture, in F. Nicolis (ed.) Bell Beakers today: pottery, people, culture, symbols in prehistoric Europe: 487-96. Trento: Servicio Beni Culturali, Provincia Autonoma di Trento.

Buck, C.E., C.D. LiTTON \& A.F.M. SMITH. 1992. Calibration of radiocarbon results pertaining to related archaeological events. Journal of Archaeological Science 19: 497-512. http://dx.doi.org/10.1016/0305-4403(92)90025-X

BuCK, C.E., W.G. CAVANAGH \& C.D. LitTON. 1996. Bayesian approach to interpreting archaeological data. Chichester: Wiley.

Burgess, C. \& S. SHENnAN. 1976. The Beaker phenomenon: some suggestions, in C. Burgess \& R. Miket (ed.) Settlement and economy in the third and second millennia BC (British Archaeological Reports British series 33): 309-31. Oxford: British Archaeological Reports.

Chenery, C.A. \& J.A. Evans. 2011. A summary of the strontium and oxygen isotope evidence for the origins of Bell Beaker individuals found near Stonehenge, in A.P. Fitzpatrick The Amesbury Archer and the Boscombe Bowmen: Bell Beaker burials at Boscombe Down, Amesbury, Wiltshire (Wessex Archaeology 27): 185-90. Salisbury: Wessex Archaeology.

CHILDE, V.G. 1925. The dawn of European civilisation. London: Kegan Paul.

- 1929. The Danube in prehistory. Oxford: Clarendon.

Clarke, D.L. 1970. Beaker pottery of Great Britain and Ireland. Cambridge: Cambridge University Press.

CurTis, N. \& N. WILKIN. 2012. The regionality of Beakers and bodies in the Chalcolithic of north-east Scotland, in M.J. Allen, J. Gardiner \& A. Sheridan (ed.) Is there a British Chalcolithic? People, place and polity in the late 3rd millennium: 237-56. Oxford: Oxbow.

Desideri, J. \& M. Besse. 2010. Swiss Bell Beaker population dynamics: eastern or southern influences? Archaeological and Anthropological Sciences 2: 157-73. http://dx.doi.org/10.1007/s12520-010-0037-9

Evans, J.A. \& C.A. Chenery. 2011. Isotope studies, in A.P. Fitzpatrick The Amesbury Archer and the Boscombe Bowmen: Bell Beaker burials at Boscombe Down, Amesbury, Wiltshire (Wessex Archaeology 27): 32. Salisbury: Wessex Archaeology.
Evans, J.A., C.A. Chenery \& A.P. FitzPATrick. 2006. Bronze Age childhood migration of individuals near Stonehenge revealed by strontium and oxygen isotope tooth enamel analysis. Archaeometry 48: 309-21. http://dx.doi.org/10.1111/j.1475-4754. 2006.00258.x

Evans, J.E., C.A. Chenery \& J. Montgomery. 2012. A summary of strontium and oxygen isotope variation in archaeological human tooth enamel excavated from Britain. Journal of Analytical Atomic Spectrometry 27: 754-64. http://dx.doi.org/10.1039/c2ja10362a

FitZPATRICK, A.P. 2011. The Amesbury Archer and the Boscombe Bowmen: Bell Beaker burials at Boscombe Down, Amesbury, Wiltshire (Wessex Archaeology 27). Salisbury: Wessex Archaeology.

GerHARDT, K. 1976. Anthropotypologie der Glockenbecherleute in ihren Ausschwärmelandschaften, in J.N. Lanting \& J.D. van der Waals (ed.) Glockenbecher Symposium, Oberried 1974: 147-64. Bussum/Haarlem: Fibula-van Dischoeck.

Grupe, G., T.D. Price, P. Schröter, F. SÖllner, C.M. JOHNSON \& B.L. BEARD. 1997. Mobility of Bell Beaker people revealed by strontium isotope ratios of tooth and bone: a study of southern Bavarian skeletal remains. Applied Geochemistry 12: 517-25. http://dx.doi.org/10.1016/S08832927(97)00030-9

Grupe, G., T.D. Price \& F. Söllner. 1999. Mobility of Bell Beaker people revealed by strontium isotope ratios of tooth and bone: a study of southern Bavarian skeletal remains. A reply to the comment by Peter Horn \& Dieter Müller-Sohnius. Applied Geochemistry 14: 271-75.

Grupe, G., T.D. Price \& P. Schröter. 2001. Zur Mobilität in der Skelettfunde, in A. Lippert, M. Schultz, S. Shennan \& M. Teschler-Nicola (ed.) Mensch und Umweld während des Neolithikums und der Frühbronzezeit in Mitteleuropa: 207-13. Rahden: Marie Leidorf.

HaAk, W., I. Lazaridis, N. Patterson, N. Rohland, S. Mallick, B. Llamas, G. Brandt, S. Nordenfelt, E. Harney, K. Stewardson, Q. Fu, A. MitTnik, E. BÁnfFy, C. ECONOMOU, M. Francken, S. Friedrich, R. Garrido Pena, F. Hallgren, V. Khartanovich, A. KhoKhlov, N. Kunst, P. KuZnetsov, H. MELler, O. Mochalov, V. Moiseyev, N. Nicklisch, S.L. Pichler, R. Risch, N.A. RoJo GUERrA, C. Roth, A. SzÉcsényI-NAgY, J. WAHL, M. Meyer, J. Krause, D. Brown, D. Anthony, A. CoOper, K.W. Alt \& D. ReICH. 2015. Massive migration from the steppe was a source for Indo-European languages in Europe. Nature 522: 207-11. http://dx.doi.org/10.1038/nature14317 
Harding, J. \& F. Healy. 2007. The Raunds Area Project: a Neolithic and Bronze Age landscape in Northamptonshire. Swindon: English Heritage.

Hervella, M., M. Rotea, N. Izagirre, M. Constantinescu, S. Alonso, M. IoAna, C. LAZĂR, F. RIDICHE, A.D. SOFICARU, M.G. NeTEA \& C. DE-LA-RUA. 2015. Ancient DNA from south-east Europe reveals different events during Early and Middle Neolithic influencing the European genetic heritage. PLoS ONE 10(6): e0128810.

http://dx.doi.org/10.1371/journal.pone0128810.

JaY, M. \& M.P. Richards. 2007. The Beaker People Project: progress and prospects for the carbon, nitrogen and sulphur isotopic analysis of collagen, in M. Larsson \& M. Parker Pearson (ed.) From Stonehenge to the Baltic: cultural diversity in the third millennium BC (British Archaeological Reports international series 1692): 77-82. Oxford: British Archaeological Reports.

Jay, M., M. Parker Pearson, M.P. Richards, O. Nehlich, J. Montgomery, A. Chamberlain \& A. Sheridan. 2012. The Beaker People Project: an interim report on the progress of the isotopic analysis of the organic skeletal material, in M.J. Allen, J. Gardiner \& A. Sheridan (ed.) Is there a British Chalcolithic? People, place and polity in the late 3rd millennium: 226-36. Oxford: Oxbow.

LÉvi-STRAUSS, C. 1969. The elementary structures of kinship. London: Eyre \& Spottiswoode.

MaHONEY, P. 2007. Microwear studies of diet in Early Bronze Age burials from Scotland, in M. Larsson \& M. Parker Pearson (ed.) From Stonehenge to the Baltic: cultural diversity in the third millennium $B C$ (British Archaeological Reports international series 1692): 83-89. Oxford: British Archaeological Reports.

MCKinleY, J. 2011. Human remains (graves 1236 and 1289), in A.P. Fitzpatrick The Amesbury Archer and the Boscombe Bowmen: Bell Beaker burials at Boscombe Down, Amesbury, Wiltshire (Wessex Archaeology 27): 77-87. Salisbury: Wessex Archaeology.

Montgomery, J. 2010. Passports from the past: investigating human dispersals using strontium isotope analysis of tooth enamel. Annals of Human Biology 37: 325-46.

http://dx.doi.org/10.3109/03014461003649297

Montgomery, J., J.A. Evans \& R.E. CoOper. 2007. Resolving archaeological populations with Sr-isotope mixing models. Applied Geochemistry 22: 1502-14. http://dx.doi.org/10.1016/j. apgeochem.2007.02.009
Montgomery, J., J.A. Evans \& M.S.A. Horstwood. 2010. Evidence for long-term averaging of strontium in bovine enamel using TIMS and LA-MC-ICP-MS strontium isotope intra-molar profiles. Environmental Archaeology 15: 32-42. http://dx.doi.org/10.1179/ 146141010X12640787648694

Moody, G.A. 2008. The Isle of Thanet from prehistory to the Norman Conquest. Stroud: Tempus.

Müller, J. \& S. van Willigen. 2001. New radiocarbon evidence for European Bell Beakers and the consequences for the diffusion of the Bell Beaker phenomenon, in F. Nicolis (ed.) Bell Beakers today: pottery, people, culture, symbols in prehistoric Europe: 59-80. Trento: Servicio Beni Culturali, Provincia Autonoma di Trento.

NeEdHAM, S. 2005. Transforming Beaker culture in north-west Europe: processes of fusion and fission. Proceedings of the Prehistoric Society 71: 171-217. http://dx.doi.org/10.1017/S0079497X00001006

- 2007. Isotopic aliens: Beaker movement and cultural transmissions, in M. Larsson \& M. Parker Pearson (ed.) From Stonehenge to the Baltic: cultural diversity in the third millennium $B C$ (British Archaeological Reports international series 1692): 41-46. Oxford: British Archaeological Reports.

- 2012. Case and place for the British Chalcolithic, in M.J. Allen, J. Gardiner \& A. Sheridan (ed.) Is there a British Chalcolithic: people, place and polity in the late 3rd millennium: 1-26. Oxford: Oxbow.

Needham, S., M. Parker Pearson, A. Tyler, M.P. RichardS \& M. JaY. 2010. A first 'Wessex I' date from Wessex. Antiquity 84: 363-73. http://dx.doi.org/10.1017/S0003598X00066631

Parker Pearson, M., A. Chamberlain, M. Jay, M.P. RICHARDS \& A. SHERIDAN (ed.). Forthcoming. The Beaker People: isotopes, mobility and diet in prehistoric Britain. Oxford: Oxbow.

Piggott, S. 1938. The Early Bronze Age in Wessex. Proceedings of the Prehistoric Society 4: 52-106. http://dx.doi.org/10.1017/S0079497X00021137

Price, T.D., G. Grupe \& P. SCHröter. 1994. Reconstruction of migration patterns in the Bell Beaker period by stable strontium isotope analysis. Applied Geochemistry 9: 413-17. http://dx.doi.org/10.1016/0883-2927(94)90063-9

- 1998. Migration and mobility in the Bell Beaker period in Central Europe. Antiquity 72: 405-11. http://dx.doi.org/10.1017/S0003598X00086683

Price, T.D., C. Knipper, G. Grupe \& V. SmrCKA. 2004. Strontium isotopes and prehistoric human migration: the Bell Beaker period in Central Europe. European Journal of Archaeology 7: 9-40. http://dx.doi.org/10.1177/1461957104047992 


\section{Beaker people in Britain}

VANDER LINDEN, M. 2006. Le phénomène campaniforme dans l'Europe du 3ème millénaire avant notre ère (British Archaeological Reports international series 1470). Oxford: British Archaeological Reports.

-2007 . What linked the Bell Beakers in thirdmillennium BC Europe? Antiquity 81: 343-52. http://dx.doi.org/10.1017/S0003598X00095223

VAN KLINKEN, G.J. 1999. Bone collagen quality indicators for palaeodietary and radiocarbon measurements. Journal of Archaeological Science 26: 687-95. http://dx.doi.org/10.1006/jasc.1998.0385
VAN Klinken, G.J., H. VAN DER Plicht \& R.E.M. HedGes. 1994. Bone ${ }^{13} \mathrm{C} /{ }^{12} \mathrm{C}$ ratios reflect (palaeo-)climatic variations. Geophysical Research Letters 21: 445-48. http://dx.doi.org/10.1029/94GL00177

WADDELL, J. 1978. The invasion hypothesis in Irish prehistory. Antiquity 52: 121-28. http://dx.doi.org/10.1017/S0003598X00071945

WILKIN, N. 2014. Food vessel pottery from Early Bronze Age funerary contexts in northern England: a typological and contextual study. Unpublished PhD thesis, University of Birmingham.

WILSON, D. 1863. The prehistoric annals of Scotland. London: Macmillan.

WOODWARD, P.J. 1980. A Beaker burial from Rimbury, Dorset. Proceedings of the Dorset Natural History and Archaeological Society 102: 98-100.

Received: 3 April 2015; Accepted: 30 June 2015; Revised: 27 August 2015 